\section{Controlled Delayed Cooling Extends Peach Market Life}

\author{
Carlos H. Crisosto, ${ }^{1}$ \\ David Garner, 2 \\ Harry L. Andris, ${ }^{3}$ and \\ Kevin R. Day ${ }^{4}$
}

\begin{abstract}
AdDITIONAL INDEX WORDS. internal breakdown, chilling injury, mealiness, flesh browning, decay, softening, preconditioning, consumers, Prunus persica
\end{abstract}

\begin{abstract}
Summary. A commercial controlled delayed cooling or preconditioning treatment was developed to extend peach (Prunus persica) market life of the most popular California peach cultivars. A 24 to $48 \mathrm{~h}$ cooling delay at $68{ }^{\circ} \mathrm{F}\left(20.0^{\circ} \mathrm{C}\right)$ was the most effective treatment for extending market life of internal breakdown susceptible peaches without causing fruit deterioration. This treatment increased minimum market life by up to 2 weeks in the cultivars tested. Weight loss and softening occurred during the controlled delayed cooling treatments, but did not reduce fruit quality. Detailed monitoring of these fruit quality changes during the delayed cooling period and proper use of fungicides is highly recommended for success in this new fruit delivery system. Rapid cooling after preconditioning is important to stop further fruit deterioration such as flesh softening, senescence, decay and weight loss. Controlled delayed cooling can also be used to pre-ripen susceptible and nonsusceptible peaches to deliver a readyto-buy product to the consumer.
\end{abstract}

S ome of the most frequent complaints by peach consumers and store produce managers are the presence of off-flavors, flesh mealiness (dry fruit or woolliness), flesh browning, and lack of ripening(Bruhn et al., 1991). These symptoms are a consequence of internal breakdown (IB) also called ${ }^{1}$ Corresponding author; Pomology Department, University of California, Davis, CA 95616, located at Kearney Agricultural Center, 9240 S. Riverbend Avenue, Parlier, CA 93648 .

${ }^{2}$ Pomology Department, University of California, Davis, CA 95616, located at Kearney Agricultural Center, 9240 S. Riverbend Avenue, Parlier, CA 93648.

${ }^{3}$ University of California Cooperative Extension, Fresno County, 1720 S. Maple Avenue, Fresno, CA 93702.

${ }^{4}$ University of California Cooperative Extension, Tulare County, 4437 S. Laspina St., Ste. B, Tulare, CA 93274. chilling injury (CI). This disorder is the main limitation to the marketing of some peach cultivars (Mitchell and Kader, 1989). Because these symptoms normally appear after ripening fruit at room temperature following cold storage, this problem is usually experienced by the consumers, not the growers, packers and/or buyers (Crisosto et al., 1997; Von Mollendorff, 1987).

Among IB susceptible peach cultivars, the greatest expression of the IB symptoms occurs after storage at temperatures between 36 and $46{ }^{\circ} \mathrm{F}$ $\left(2.2\right.$ and $7.8^{\circ} \mathrm{C}$ ) (Haller, 1952; Harding and Haller, 1934; Mitchell and Kader, 1989; Smith, 1934). This range of temperatures has been named the killing temperature range because of its adverse effect on tree fruit market life (Crisosto, 1997). While IB symptoms will still develop at $32{ }^{\circ} \mathrm{F}\left(0.0^{\circ} \mathrm{C}\right)$ or below, they develop more slowly and normally these symptoms become less intense than at higher temperatures. Unfortunately, in our study of fruit pulp temperatures after $3 \mathrm{~d}$ of domestic transportation we found that $80 \%$ of the peach shipments arrived within the killing temperature range. In most of the IB susceptible peach cultivars, market life is dramatically reduced when fruit are exposed to this temperature range for 3 to $7 \mathrm{~d}$. For example, 'Elegant Lady' peach market life can be reduced from at least 3 weeks at $32^{\circ} \mathrm{F}$ to only 1 week by exposing fruit to 41 ${ }^{\circ} \mathrm{F}\left(5.0^{\circ} \mathrm{C}\right.$ ) for 5 to $7 \mathrm{~d}$ (Crisosto et al., 1999b). 'O'Henry' peaches developed visual mealiness symptoms after 2 weeks storage at $41^{\circ} \mathrm{F}$; however, trained judges were able to detect off-flavors or mealy texture 1 week before the visual symptom appeared. The early loss of flavor or off-flavor development demonstrates the significance of this problem to the consumer. With 'O'Henry' peaches, flesh browning was observed after week $3, \approx 1$ week later than mealiness symptoms (Crisosto and Labavitch, 2002). The role of temperature in IB symptom expression is important, but genetic background (Anderson, 1979; Crisosto et al., 1999a; Harding and Haller, 1934), maturity (Von Mollendorff, 1987), and orchard factors (Crisosto et al., 1994, 1997, 1999b) are also involved.

The current University of California recommendations for IB susceptible peaches are to cool the fruit pulp to near $32^{\circ} \mathrm{F}$ within 8 h of harvesting, keep fruit at this temperature, and avoid expos- ing the fruit to the killing temperature range (Mitchell, 1987). Based on this information, a temperature management protocol for packers and shippers and a ripening protocol for fruit handlers and retailers has been developed (Crisosto, 1997; Mitchell and Kader, 1989). However, temperature management becomes difficult during the hot months of July and August when large volumes of IB susceptible peaches are harvested in California and transported out of state. These cultivars are routinely exposed to the killing temperature range during transportation and/or retail handling, and our current recommendations to reduce IB have not solved the problem in many cases.

Delayed cooling and/or intermittent warming treatments (Anderson, 1979; Nanos and Mitchell, 1991) were promising in controlling IB. Our work consisted of developing a commercially viable controlled delayed cooling protocol based on this concept.

\section{Materials and methods}

During the 1999 season, controlled delayed cooling experiments were conducted with three important freestone peach cultivars: 'Flavorcrest', 'Elegant Lady', and 'O'Henry'. In the 2000 season, 'Summer Lady', 'Zee Lady', and 'Ryan Sun' freestone peaches were evaluated. In both seasons, size $50[\approx 6.6 \mathrm{oz}(186 \mathrm{~g})]$ peaches were washed, brushed, and coated with a mix of mineral wax and iprodione fungicide to prevent storage disease development, and packed into $24-\mathrm{lb}$ (10.9-kg) boxes at a commercial packinghouse without cooling. After packaging, the boxes were transported $8 \mathrm{~km}$ to the University of California, Postharvest Laboratory at the Kearney Agricultural Center, Parlier (KAC).

In 1999, we evaluated five delayed cooling temperature treatments. The treatments consisted of exposure of the fruit to temperatures of 41, 50 (10.0 ${ }^{\circ} \mathrm{C}$ ), or $68^{\circ} \mathrm{F}$ for 24 or $48 \mathrm{~h}$. Fruit that were cooled to 32 or $4 l^{\circ} \mathrm{F}$ within 8 $\mathrm{h}$ of harvest (no delay or fast cooling) were used as the control. During the 2000 season, we focused on the best preconditioning treatments selected from the 1999 season, 24 and $48 \mathrm{~h}$ at $68^{\circ} \mathrm{F}$, plus the no delay treatment. Three and five replications (boxes) per treatment were used in the 1999 and 2000 seasons, respectively. After receiving the fruit from the packinghouse, all of the boxes were put in a forced-air 
cooler with an air supply temperature of $32^{\circ} \mathrm{F}$. The pulp temperature of the fruit was monitored, and these fruit were removed when they reached their target delay temperature $\left(68,50\right.$, or $\left.41^{\circ} \mathrm{F}\right)$. After removal from the cooling tunnel, the boxes were transferred to a controlled temperature room set at the appropriate delay temperature and held there for the specified length of time (24 or $48 \mathrm{~h}$ ). Control fruit that required cooling to $32{ }^{\circ} \mathrm{F}$ (no delay or fast cooling) remained in the forced air room until they reached a pulp temperature of $\approx 34$ ${ }^{\circ} \mathrm{F}\left(1.1^{\circ} \mathrm{C}\right)(\approx 6 \mathrm{~h})$ before being placed in the $32^{\circ} \mathrm{F}$ cold room. Following the required cooling delay of 24 or $48 \mathrm{~h}$, treated fruit were forced air cooled to a storage temperature of either 32 or $41^{\circ} \mathrm{F}$ for further quality and market life determinations.

Fruit quality was measured on the day of harvest as well as after the 24 and 48-h delays. Ten fruit from each of the three (1999) and five (2000) replications per treatment were used to determine fruit weight $(\mathrm{g})$, overall red color (\%), soluble solids concentration (\% SSC), $\mathrm{pH}$, titratable acidity (\% malic acid), and firmness [pounds force (lbf)] of the fruit at both cheeks, tip, suture, and shoulder as previously described (Crisosto et al., 1994). Another 30 fruit from each replication per treatment were removed from storage on $10 \mathrm{~d}$ (1999) or $7 \mathrm{~d}$ (2000) intervals to measure firmness and market life according to our previously published protocol (Crisosto etal., 1999; Garner et al, 2001). After each storage period, the fruit were warmed to room temperature and flesh firmness of 15 fruit per replication-treatment was evaluated immediately. The remaining 15 fruit per replication-treatment were kept in a ripening room at $68^{\circ} \mathrm{F}$ with $85 \%$ humidity to trigger ripening for subsequent internal breakdown evaluation. Firmness changes during fruit ripening were monitored. When firmness reached 2 to $4 \mathrm{lbf}$ ( 8.9 to 17.8 $\mathrm{N}$ ), fruit were evaluated for internal breakdown symptoms. Two different market life potentials were calculated for each cultivar (Crisosto et al., 1999). The maximum market life was the number of weeks a cultivar could be stored under optimal conditions $\left(32^{\circ} \mathrm{F}\right)$ before IB symptoms became limiting, and the minimum market life was the number of the weeks it could be stored under poor conditions $\left(4 \mathrm{I}^{\circ} \mathrm{F}\right)$. A cultivar was determined to have reached the end of its market life when $\geq 25 \%$ of the fruit became mealy or leathery, had flesh browning, or severe flesh bleeding (Nanos and Mitchell, 1991).

\section{Results and discussion}

FIRMNESS (1999 SEASON). Among the three cultivars tested during the 1999 season, neither SSC nor TA was significantly affected by any of the delayed cooling treatments (data not shown). Fruit flesh firmness at harvest and during storage depended on the position of measurement on the fruit. Among all cultivars in this test, the firmest position on the fruit was the cheek. For 'Flavorcrest' peaches, the softest position was at the suture; while for 'Elegant Lady' and 'O'Henry' peaches the softest position was at the shoulder. There was generally a 3 to $5 \mathrm{lbf}(13.3$ to $22.2 \mathrm{~N}$ ) difference in flesh firmness between the firmest and softest positions. The preconditioning process led to varying degrees of flesh softening depending on temperature and duration, but the relative difference due to position of measurement generally remained (Table 1 ).

'Flavorcrest' peach cheek firmness decreased by about $5 \mathrm{lbf}$ after the $48 \mathrm{~h}$ cooling delay at $68^{\circ} \mathrm{F}$. Although some softening occurred during the $24 \mathrm{~h}$ cooling delay at $68^{\circ} \mathrm{F}$ and the $48 \mathrm{~h}$ cooling delay at $50{ }^{\circ} \mathrm{F}$, peach cheek firmnesses were not significantly different from that of control fruit (Table 1). The softest suture firmness ( $4 \mathrm{lbf}$ ) occurred on fruit from the 48 h cooling delay treatment at $68^{\circ} \mathrm{F}$. Suture flesh firmness decreased by about 5 lbf during this delay treatment. Significant softening also occurred during the 24 h delay at $68^{\circ} \mathrm{F}$ with a $3 \mathrm{lbf}$ decrease in suture firmness. The highest suture firmness was measured on fruit immediately cooled and fruit from the $41^{\circ} \mathrm{F}$ delay cooling treatments $(24$ or $48 \mathrm{~h}$ delay). Immediately cooling to $32{ }^{\circ} \mathrm{F}$ after preconditioning stopped any further flesh softening in all of the preconditioning treatments during subsequent storage at $32^{\circ} \mathrm{F}$. After 20 d storage at $32{ }^{\circ} \mathrm{F}$, fruit from the $48 \mathrm{~h}$ delayed cooling treatment at $68^{\circ} \mathrm{F}$ still had the lowest fruit firmness measured on the cheek [6.5 $\operatorname{lbf}(28.91 \mathrm{~N})]$ and suture $(4 \mathrm{lbf})$. Fruit from the $24 \mathrm{~h}$ delay at $68{ }^{\circ} \mathrm{F}$ and the $48 \mathrm{~h}$ delay at 50 ${ }^{\circ} \mathrm{F}$ were also significantly softer at the suture than control fruit.

At harvest and after the different delayed cooling treatments, the firmest position on 'Elegant Lady' and 'O'Henry' peaches was the cheek and the softest was the shoulder (Table 1). 'Elegant Lady' peaches lost about 7 lbf $(31.1 \mathrm{~N})$ firmness at the cheek and $5 \mathrm{lbf}$ firmness at the shoulder during the $48 \mathrm{~h}$ cooling delay at $68^{\circ} \mathrm{F}$, while fruit cooled immediately or had cooling delayed for $24 \mathrm{~h}$ at 41 or $50^{\circ} \mathrm{F}$ did not lose any flesh firmness. Fruit from the 24 h delay at $68^{\circ} \mathrm{F}$ lost about $3 \mathrm{lbf}$ at the cheek and $4 \mathrm{lbf}$ at the suture during the cooling delay. Immediate cooling to a pulp temperature of $32{ }^{\circ} \mathrm{F}$ after the cooling delay treatments arrested further softening during subsequent $32{ }^{\circ} \mathrm{F}$ cold storage for all but the 48 $\mathrm{h}$ at $68^{\circ} \mathrm{F}$ delay treatment. This treatment continued to soften between the 10 and $20 \mathrm{~d}$ storage period to a final flesh firmness of $4.9 \mathrm{lbf}(21.80 \mathrm{~N})$ at the cheek and $3.8 \mathrm{lbf}(16.90 \mathrm{~N})$ at the shoulder.

Similar rates of softening during preconditioning occurred with 'O'Henry' peaches. Fruit firmness was significantly affected by the temperature and length of exposure to the cooling delay treatments. The softest flesh firmnesses were measured on fruit from the $48 \mathrm{~h}$ cooling delay treatment at $68{ }^{\circ} \mathrm{F}$, while firmnesses remained high in the other treatments. Unlike 'Elegant Lady' peaches, immediate cooling after preconditioning stopped further softening in all of the preconditioning treatments for 'O'Henry' peaches stored at $32^{\circ} \mathrm{F}$.

INTERNALBREAKDOWN(1999SEASON). In 1999, flesh browning and flesh bleeding symptoms were not observed in any of the preconditioned 'Flavorcrest', 'Elegant Lady' or 'O'Henry' peaches after $20 \mathrm{~d}$ storage at $32^{\circ} \mathrm{F}$. Although a low incidence of decay was observed, it was not significant or correlated with the treatments (data not shown). Flesh mealiness was not observed in any treatment after $20 \mathrm{~d}$ storage at $32^{\circ} \mathrm{F}$ or $10 \mathrm{~d}$ at $4 \mathrm{l}^{\circ} \mathrm{F}$ (data not shown). After these storage periods, all fruit from the three cultivars were still juicy.

The incidence of mealiness increased dramatically after $20 \mathrm{~d}$ storage at $41{ }^{\circ} \mathrm{F}$ (Table 2). 'Flavorcrest' peaches from the $48 \mathrm{~h}$ cooling delay treatment at $68{ }^{\circ} \mathrm{F}$ had a significantly higher percentage of juicy fruit $(93 \%)$ than the rest of the treatments ( $\leq 28 \%$ juicy fruit). None of the 'Flavorcrest' peaches that were immediately cooled were juicy after $20 \mathrm{~d}$ storage at $41^{\circ} \mathrm{F}$. With 'Elegant Lady' peaches, $97 \%$ of the fruit from the 24 and 48 h cooling delay treatments at $68^{\circ} \mathrm{F}$ remained juicy 
Table 1. Influence of controlled delayed cooling treatments on flesh firmness of three peach cultivars measured after treatments at 41,50 , or $68^{\circ} \mathrm{F}\left(5.0,10.0\right.$, or $\left.20.0{ }^{\circ} \mathrm{C}\right)$, and 10 and $20 \mathrm{~d}$ of storage at $32{ }^{\circ} \mathrm{F}\left(0.0^{\circ} \mathrm{C}\right)$ (1999 season).

\begin{tabular}{|c|c|c|c|c|c|c|}
\hline \multirow{3}{*}{$\begin{array}{l}\text { Delayed } \\
\text { cooling } \\
\text { treatments }\end{array}$} & \multicolumn{6}{|c|}{ Firmness $\left({ } b^{b} f^{z}\right)$} \\
\hline & \multicolumn{2}{|c|}{ After treatment } & \multicolumn{2}{|c|}{$10 \mathrm{~d}$ Storage } & \multicolumn{2}{|c|}{$20 \mathrm{~d}$ Storage } \\
\hline & $\begin{array}{c}\text { Firmest } \\
\text { position }^{\mathrm{y}}\end{array}$ & $\begin{array}{c}\text { Softest } \\
\text { position }^{\mathrm{x}}\end{array}$ & $\begin{array}{l}\text { Firmest } \\
\text { position }\end{array}$ & $\begin{array}{c}\text { Softest } \\
\text { position }\end{array}$ & $\begin{array}{l}\text { Firmest } \\
\text { position }\end{array}$ & $\begin{array}{c}\text { Softest } \\
\text { position }\end{array}$ \\
\hline \multicolumn{7}{|l|}{ 'Flavorcrest' } \\
\hline No delay" (control) & $11.4 \mathrm{a}^{\mathrm{v}}$ & $9.4 \mathrm{a}$ & $10.4 \mathrm{a}$ & $9.4 \mathrm{a}$ & 11.0 & $9.0 \mathrm{ab}$ \\
\hline $24 \mathrm{~h}$ at $41^{\circ} \mathrm{F}$ & $11.0 \mathrm{a}$ & $9.5 \mathrm{a}$ & $10.6 \mathrm{a}$ & $8.5 \mathrm{a}$ & 9.7 & $7.8 \mathrm{abc}$ \\
\hline $48 \mathrm{~h}$ at $41^{\circ} \mathrm{F}$ & $11.1 \mathrm{a}$ & $9.4 \mathrm{a}$ & $9.8 \mathrm{a}$ & $8.2 \mathrm{a}$ & 10.1 & $7.4 \mathrm{abc}$ \\
\hline $48 \mathrm{~h}$ at $50^{\circ} \mathrm{F}$ & $9.9 \mathrm{a}$ & $7.8 \mathrm{c}$ & $10.0 \mathrm{a}$ & $8.4 \mathrm{a}$ & 9.2 & $5.7 \mathrm{~cd}$ \\
\hline $48 \mathrm{~h}$ at $68^{\circ} \mathrm{F}$ & $6.5 \mathrm{~b}$ & $4.0 \mathrm{~d}$ & $6.0 \mathrm{c}$ & $5.3 \mathrm{~b}$ & 6.0 & $3.7 \mathrm{~d}$ \\
\hline$P$ value & $<0.0001$ & $<0.0001$ & $<0.0001$ & $<0.0001$ & NS & 0.004 \\
\hline \multicolumn{7}{|l|}{ 'Elegant Lady' } \\
\hline $48 \mathrm{~h}$ at $41^{\circ} \mathrm{F}$ & $13.9 \mathrm{~b}$ & $10.6 \mathrm{a}$ & $14.7 \mathrm{~b}$ & $11.4 \mathrm{ab}$ & $13.8 \mathrm{ab}$ & $10.6 \mathrm{a}$ \\
\hline $48 \mathrm{~h}$ at $50^{\circ} \mathrm{F}$ & $10.9 \mathrm{c}$ & $8.2 \mathrm{~b}$ & $12.4 \mathrm{a}$ & $10.2 \mathrm{~b}$ & $11.4 \mathrm{c}$ & $9.6 \mathrm{a}$ \\
\hline $48 \mathrm{~h}$ at $68^{\circ} \mathrm{F}$ & $7.7 \mathrm{~d}$ & $6.4 \mathrm{c}$ & $7.1 \mathrm{c}$ & $4.9 \mathrm{c}$ & $4.5 \mathrm{~d}$ & $3.8 \mathrm{~b}$ \\
\hline$P$ value & $<0.0001$ & $<0.0001$ & $<0.0001$ & $<0.0001$ & $<0.0001$ & $<0.0001$ \\
\hline \multicolumn{7}{|l|}{ 'O'Henry' } \\
\hline No delay (control) & $13.5 \mathrm{a}$ & $7.7 \mathrm{a}$ & $12.8 \mathrm{a}$ & $7.6 \mathrm{a}$ & $12.6 \mathrm{a}$ & $7.5 \mathrm{a}$ \\
\hline $24 \mathrm{~h}$ at $41^{\circ} \mathrm{F}$ & $13.1 \mathrm{ab}$ & $7.7 \mathrm{a}$ & $12.3 \mathrm{abc}$ & $6.6 \mathrm{a}$ & $11.7 \mathrm{ab}$ & $6.9 \mathrm{ab}$ \\
\hline $24 \mathrm{~h}$ at $50^{\circ} \mathrm{F}$ & $13.4 \mathrm{a}$ & $7.8 \mathrm{a}$ & $11.2 \mathrm{bc}$ & $6.5 \mathrm{a}$ & $9.1 \mathrm{bc}$ & $5.4 \mathrm{~cd}$ \\
\hline $24 \mathrm{~h}$ at $68^{\circ} \mathrm{F}$ & $12.1 \mathrm{bc}$ & $7.1 \mathrm{a}$ & $9.8 \mathrm{c}$ & $4.6 \mathrm{~b}$ & $8.6 \mathrm{bcd}$ & $4.6 \mathrm{~cd}$ \\
\hline $48 \mathrm{~h}$ at $41^{\circ} \mathrm{F}$ & $11.4 \mathrm{c}$ & $7.6 \mathrm{a}$ & $12.7 \mathrm{ab}$ & $7.6 \mathrm{a}$ & $11.5 \mathrm{ab}$ & $6.5 \mathrm{ab}$ \\
\hline $48 \mathrm{~h}$ at $50^{\circ} \mathrm{F}$ & $11.3 \mathrm{c}$ & $7.4 \mathrm{a}$ & $11.0 \mathrm{c}$ & $6.5 \mathrm{a}$ & $9.7 \mathrm{~b}$ & $5.8 \mathrm{abc}$ \\
\hline $48 \mathrm{~h}$ at $68^{\circ} \mathrm{F}$ & $7.5 \mathrm{~d}$ & $4.1 \mathrm{~b}$ & $7.5 \mathrm{~d}$ & $4.4 \mathrm{~b}$ & $6.5 \mathrm{~d}$ & $3.9 \mathrm{~d}$ \\
\hline
\end{tabular}

${ }^{\mathrm{z}} 1.0$ pound force $(\mathrm{lbf})=4.448 \mathrm{~N}$.

y The firmest position on the fruit for all cultivars was the cheek.

'The softest position on 'Flavorcrest' peaches was the suture; for all other cultivars it was the shoulder.

"Fruit were cooled to a pulp temperature of $32^{\circ} \mathrm{F}$ within 6 to $8 \mathrm{~h}$ of harvest and maintained at this temperature.

"Mean separation by least significant difference test at $P>0.05$.

after $20 \mathrm{~d}$ storage at $41^{\circ} \mathrm{F}$. Only $43 \%$ of the fruit that had been cooled immediately and stored at $41^{\circ} \mathrm{F}$ remained juicy. Among fruit that had cooling delayed for 24 or 48 h at $50{ }^{\circ} \mathrm{F}, 68 \%$ and $46 \%$ remained juicy, respectively. Results for 'O'Henry' peaches were similar. All of the fruit from the 24 and $48 \mathrm{~h}$ cooling delay treatments at $68^{\circ} \mathrm{F}$ remained juicy, and only $55 \%$ of the fruit that had been cooled immediately and stored at 41 ${ }^{\circ} \mathrm{F}$ remained juicy. Among fruit that had cooling delayed for 24 or $48 \mathrm{~h}$ at $50{ }^{\circ} \mathrm{F}, 78 \%$ and $77 \%$ remained juicy, respectively.

Weight Loss (1999 SEASON). Fruit weight losses measured during the treatment and storage periods were similar for the three cultivars evaluated (data not shown). For this reason, only the 'Elegant Lady' data will be discussed. Weight loss measured immediately after the delayed cooling treatments was very low in all of the treatments. Fruit from the $48 \mathrm{~h}$ cooling delay treatment at 68 ${ }^{\circ} \mathrm{F}$ lost the most weight $(0.8 \%)$, while fruit that was immediately cooled lost the least $(0.6 \%)$; but these differences are considered commercially unimportant. After $20 \mathrm{~d}$ of cold storage the amount of weight loss increased and ranged from $2.9 \%$ for fruit from the $48 \mathrm{~h}$ cooling delay treatment at $68{ }^{\circ} \mathrm{F}$ to $2.3 \%$ for fruit that were immediately cooled. In previous work (Crisosto et al., 1994) we found that peach shriveling symptoms became apparent when weight loss exceeded $10 \%$ of the initial fresh weight. The weight losses observed in this trial after the preconditioning

Table 2. Influence of controlled delayed cooling treatments at 50 or $68{ }^{\circ} \mathrm{F}(10.0$ or $20.0{ }^{\circ} \mathrm{C}$ ) on the percentage of 'Flavorcrest', 'Elegant Lady', and 'O'Henry' peaches remaining juicy after $20 \mathrm{~d}$ storage at $41^{\circ} \mathrm{F}\left(5.0^{\circ} \mathrm{C}\right)(1999$ season $)$.

\begin{tabular}{lccc}
\hline $\begin{array}{l}\text { Delayed } \\
\text { cooling } \\
\text { treatments }\end{array}$ & \multicolumn{3}{c}{ Juicy (\%) } \\
\cline { 2 - 4 } & 'Flavorcrest' & 'Elegant Lady' & 'O'Henry' \\
\hline No delay ${ }^{z}$ (control) & $0 \mathrm{~b}^{\mathrm{y}}$ & $43 \mathrm{~b}$ & $55 \mathrm{~b}$ \\
$24 \mathrm{~h}$ at $50^{\circ} \mathrm{F}$ & $7 \mathrm{~b}$ & $68 \mathrm{ab}$ & $78 \mathrm{ab}$ \\
$24 \mathrm{~h}$ at $68^{\circ} \mathrm{F}$ & $28 \mathrm{~b}$ & $97 \mathrm{a}$ & $100 \mathrm{a}$ \\
48 h at $50^{\circ} \mathrm{F}$ & $20 \mathrm{~b}$ & $46 \mathrm{~b}$ & $77 \mathrm{ab}$ \\
$48 \mathrm{~h}$ at $68^{\circ} \mathrm{F}$ & $93 \mathrm{a}$ & $97 \mathrm{a}$ & $100 \mathrm{a}$ \\
$P$ value & 0.001 & $<0.0001$ & 0.01 \\
\hline
\end{tabular}

${ }^{2}$ Fruit were cooled to a pulp temperature of $41^{\circ} \mathrm{F}$ within 6 to $8 \mathrm{~h}$ of harvest and maintained at this temperature. ${ }^{y}$ Mean separation by least significant difference test at $P>0.05$. 


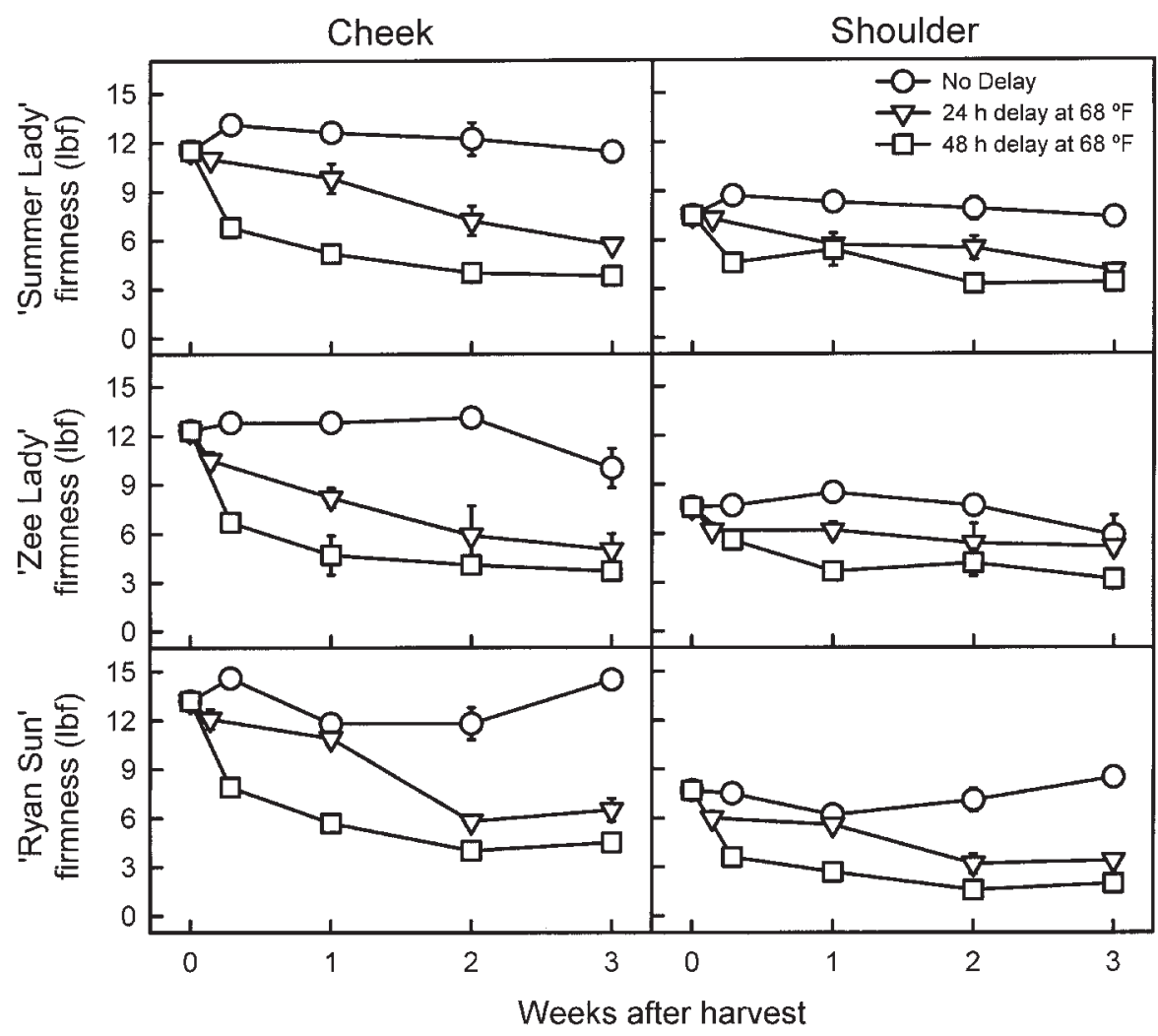

Fig. 1. Cheek and shoulder firmness of 'Summer Lady', 'Zee Lady', and 'Ryan Sun' peaches that were either immediately cooled or preconditioned at $68^{\circ} \mathrm{F}$ $\left(20.0^{\circ} \mathrm{C}\right)$ for 24 or $48 \mathrm{~h}$ before storage at $32^{\circ} \mathrm{F}\left(0.0^{\circ} \mathrm{C}\right)$ for 3 weeks $(2000$ season). Vertical bars represent $\pm \mathrm{SE} ; 1$ pound force $(\mathrm{lbf})=4.448 \mathrm{~N}$.

treatments and subsequent $20 \mathrm{~d}$ cold storage at $32{ }^{\circ} \mathrm{F}$ did not cause any visible water loss symptoms. However, it is important to remember that water loss is cumulative with some percentage lost during harvest, and then more during packaging, storage, distribution, and marketing. For this reason, we recommended keeping weight loss to a minimum during the controlled delayed cooling treatment to assure an acceptable cosmetic presentation to consumers.

Firmness (2000 SEASON). During the 1999 season, the cooling delay treatments at $68{ }^{\circ} \mathrm{F}$ were more effective than the delays at 41 or $50{ }^{\circ} \mathrm{F}$ in preventing the expression of internal breakdown symptoms after subsequent cold storage. Therefore, for the 2000 season we eliminated the 41 and 50 ${ }^{\circ} \mathrm{F}$ delay treatments and compared the 24 and $48 \mathrm{~h}$ cooling delays at $68^{\circ} \mathrm{F}$ to immediate cooling (no delay). For the three cultivars tested during the 2000 season, neither SSC nor TA were significantly affected by any of the delayed cooling treatments (data not shown).

Fruit flesh firmness at harvest and during storage was again found to be dependent upon the position of measurement on the fruit. For 'Summer Lady', 'Zee Lady', and 'Ryan Sun' peaches the firmest position on the fruit was the cheek and the softest was the shoulder. There was generally a 3 to $5 \mathrm{lbf}$ difference in flesh firmness between the firmest and softest positions. Changes in fruit flesh firmness measured during the cooling delay period and subsequent cold storage $\left(32^{\circ} \mathrm{F}\right)$ were similar to those observed in 1999. During the $48 \mathrm{~h}$ controlled delayed cooling period at $68^{\circ} \mathrm{F}$, 'Summer Lady' peach flesh firmness decreased about $5 \mathrm{lbf}$ at the cheek and $3 \mathrm{lbf}$ at the suture. Dur${ }^{y}$ Mean separation by least significant difference test at $P>0.05$. ing the subsequent 3 weeks cold storage at $32{ }^{\circ} \mathrm{F}$ fruit from this treatment lost an additional $3 \mathrm{lbf}$ at the cheek and 1 $\operatorname{lbf}(4.4 \mathrm{~N})$ at the suture (Fig. 1). Fruit from the 24 h delayed cooling treatment did not soften significantly during the delay period. They did, however, soften at a steady rate during the subsequent 3 weeks storage at $32{ }^{\circ} \mathrm{F}$. During this time they lost about $5 \mathrm{lbf}$ at the cheek and $3 \mathrm{lbf}$ at the suture. Control fruit immediately cooled to $32{ }^{\circ} \mathrm{F}$ did not soften appreciably during the entire 3 week cold storage period.

'Zee Lady' and 'Ryan Sun' peaches followed a similar pattern of changes in flesh firmness during preconditioning and storage (Fig. 1). Fruit preconditioned for $48 \mathrm{~h}$ at $68^{\circ} \mathrm{F}$ had a large initial decrease in flesh firmness during the delay period, but little more during subsequent storage at $32{ }^{\circ} \mathrm{F}$. Peaches preconditioned for $24 \mathrm{~h}$ at $68^{\circ} \mathrm{F}$ did not have a large initial decrease in flesh firmness, but instead lost firmness steadily during the entire storage period. After 2 to 4 weeks storage at $32^{\circ} \mathrm{F}$, the flesh firmnesses of fruit preconditioned for 24 and 48 h at $68^{\circ} \mathrm{F}$ were similar. In all cases, control fruit (no cooling delay) stored at $32{ }^{\circ} \mathrm{F}$ did not soften appreciably during cold storage.

INTERNAL BREAKDOWN (2000 SEAson). In 2000 , flesh bleeding symptoms were not observed in any of the preconditioned 'Summer Lady', 'Zee Lady' or 'Ryan Sun' peaches after 21 $\mathrm{d}$ storage at 32 or $4 \mathrm{l}^{\circ} \mathrm{F}$. Although a low incidence of decay was observed, it was not significant or correlated with the treatments (data not shown).

Unlike the cultivars evaluated in 1999, two of the cultivars evaluated in 2000 developed internal breakdown symptoms during storage at $32^{\circ} \mathrm{F}$ (data not shown). After $21 \mathrm{~d}$ storage at $32^{\circ} \mathrm{F}$, all of the 'Zee Lady' peaches from the 24 and 48 h cooling delay treatments at $68{ }^{\circ} \mathrm{F}$ were still juicy; whereas only

Table 3. Influence of controlled delayed cooling treatments at $68^{\circ} \mathrm{F}\left(20.0{ }^{\circ} \mathrm{C}\right)$ on the percentage of 'Summer Lady', 'Zee Lady', and 'Ryan Sun' peaches remaining juicy after $21 \mathrm{~d}$ storage at $41^{\circ} \mathrm{F}\left(5.0^{\circ} \mathrm{C}\right)(2000$ season $)$.

\begin{tabular}{lccc}
\hline $\begin{array}{l}\text { Delayed } \\
\text { cooling }\end{array}$ & \multicolumn{3}{c}{ Juicy (\%) } \\
\cline { 2 - 4 } treatments & 'Summer Lady' & 'Zee Lady' & 'Ryan Sun' \\
\hline No delay $($ control) & 53 & $7 \mathrm{a}^{\mathrm{y}}$ & $47 \mathrm{a}$ \\
$24 \mathrm{~h}$ at $68^{\circ} \mathrm{F}$ & 85 & $60 \mathrm{~b}$ & $63 \mathrm{ab}$ \\
48 h at $68^{\circ} \mathrm{F}$ & 85 & $70 \mathrm{~b}$ & $100 \mathrm{~b}$ \\
$P$ value & NS & 0.059 & 0.011 \\
\hline
\end{tabular}

${ }^{2}$ Fruit were cooled to a pulp temperature of $41^{\circ} \mathrm{F}$ within 6 to $8 \mathrm{~h}$ of harvest and maintained at this temperature. 
$13 \%$ of the peaches from the control treatment were still juicy. In addition, $26 \%$ of the control fruit had flesh browning; yet $<7 \%$ of treated fruit had flesh browning. After $2 \mathrm{l} \mathrm{d}$ storage at $32^{\circ} \mathrm{F}$, all of the 'Ryan Sun' peaches from the 48 h cooling delay treatment, $93 \%$ of the peaches from the $24 \mathrm{~h}$ cooling delay treatment and $73 \%$ of the peaches from the control treatment were still juicy. Flesh browning was present in $40 \%$ of the control fruit. In this instance $27 \%$ of the fruit from the $24 \mathrm{~h}$ cooling delay treatment at $68^{\circ} \mathrm{F}$ also had flesh browning, but none of the fruit from the $48 \mathrm{~h}$ cooling delay treatment at 68 ${ }^{\circ} \mathrm{F}$ had any flesh browning.

As was the case in 1999, all three cultivars evaluated in 2000 developed internal breakdown during storage at 41 ${ }^{\circ} \mathrm{F}$. After $14 \mathrm{~d}$ storage at $41^{\circ} \mathrm{F}$, only $60 \%$ of the control 'Summer Lady' peaches were juicy while all of the fruit from the 24 and 48 h cooling delay treatments at $68^{\circ} \mathrm{F}$ were still juicy (data not shown). Results were similar after $21 \mathrm{~d}$ storage at $41{ }^{\circ} \mathrm{F}$ with $53 \%$ of the control fruit remaining juicy and $85 \%$ of the peaches from the 24 and 48 h cooling delay treatments still juicy (Table 3 ). In addition, $60 \%$ of the control fruit developed flesh browning, whereas none of the fruit from the delay treatments did.

'Zee Lady' peaches also developed internal breakdown symptoms after $14 \mathrm{~d}$ storage at $41^{\circ} \mathrm{F}$. At this time, only $33 \%$ of the control fruit (no delay) were still juicy. All of the fruit from the 24 and $48 \mathrm{~h}$ cooling delay treatments at $68^{\circ} \mathrm{F}$ were still juicy after $14 \mathrm{~d}$ at $41^{\circ} \mathrm{F}$. In addition, $40 \%$ of the control fruit, $27 \%$ of the fruit from the $24 \mathrm{~h}$ delay and none of the fruit from the $48 \mathrm{~h}$ delay had flesh browning after $14 \mathrm{~d}$ storage at $4 \mathrm{l}^{\circ} \mathrm{F}$ (data not shown). After $21 \mathrm{~d}$ storage at $4 l^{\circ} \mathrm{F},>60 \%$ of the 'Zee Lady' peaches from the 24 and $48 \mathrm{~h}$ cooling delay treatments were still juicy, while only $7 \%$ of the control fruit were juicy (Table 3 ). At this time, $73 \%$ of the control fruit, $67 \%$ of the fruit from the 24 $\mathrm{h}$ cooling delay and none of the fruit from the $48 \mathrm{~h}$ cooling delay had flesh browning (data not shown).

'Ryan Sun' peaches began to develop internal breakdown symptoms after $14 \mathrm{~d}$ storage at $41{ }^{\circ} \mathrm{F}$ (data not shown). On this evaluation date, $60 \%$ of the control fruit (no delay) and $100 \%$ of the fruit from the 24 and $48 \mathrm{~h}$ cooling delay treatments remained juicy. Flesh browning also developed in the control treatment ( $40 \%$ of the fruit) and $24 \mathrm{~h}$ cooling delay treatment $(27 \%$ of the fruit), but not the $48 \mathrm{~h}$ cooling delay treatment. After $21 \mathrm{~d}$ storage at $4 \mathrm{l}^{\circ} \mathrm{F}$, $47 \%$ of the control fruit (no delay) and $63 \%$ of the fruit from the $24 \mathrm{~h}$ cooling delay treatment at $68^{\circ} \mathrm{F}$ were still juicy. All of the peaches from the $48 \mathrm{~h} \mathrm{cool}$ ing delay at $68^{\circ} \mathrm{F}$ remained juicy after $2 \mathrm{l} \mathrm{d}$ at $4 \mathrm{l}^{\circ} \mathrm{F}$. The incidence of flesh browning also increased to $73 \%$ in the control treatment and $67 \%$ in the $24 \mathrm{~h}$ cooling delay treatment, but was still not present in the $48 \mathrm{~h}$ cooling delay treatment.

Market life (1999-2000 Seasons).

To make the results of this research more useful to our industry, we have expressed the effect of the cooling delay treatments on the market life of each cultivar under good conditions $\left(32{ }^{\circ} \mathrm{F}-\right.$ maximum market life) or poor conditions $\left(4 \mathrm{I}^{\circ} \mathrm{F}\right.$ - minimum market life) relative to the control treatment (no cooling delay). In all cases, when $\geq 25 \%$ of the fruit became mealy or had flesh browning, the market life of the fruit had ended (Nanos and Mitchell, 1991). The 48 h delayed cooling treatment at $68^{\circ} \mathrm{F}$ extended maximum market life of 'Summer Lady' and 'O'Henry' peaches by 1 week and 'Ryan Sun' peaches by 2 weeks compared to fruit that had been cooled immediately (no delay) (Table 4). The $24 \mathrm{~h}$ cooling delay treatment at $68^{\circ} \mathrm{F}$ had no effect on maximum market life. The $48 \mathrm{~h}$ cooling delay treatment at 68 ${ }^{\circ} \mathrm{F}$ also significantly extended minimum market life in all of the tested cultivars by at least 1 week (Table 4 ). The $24 \mathrm{~h}$ cooling delay treatment did increase the minimum market life of 'Summer Lady', 'Zee Lady' and 'Ryan Sun' peaches. The $24 \mathrm{~h}$ cooling delay at $68^{\circ} \mathrm{F}$ was as effective as the $48 \mathrm{~h}$ delay at extending the minimum market life only of 'Summer Lady' and 'Zee Lady' peaches.

Controlled delayed cooling can be used to precondition stone fruit susceptible to internal breakdown in order to maintain flavor and extend market life. In general, a 24 to $48 \mathrm{~h}$ cooling delay at $68^{\circ} \mathrm{F}$ was the most effective delayed cooling treatment to extend market life of internal breakdown susceptible peaches. Delayed cooling can also be used to preripen susceptible and nonsusceptible peaches in order to deliver a more ready-to-eat product to the consumer. However, weight losses and flesh firmness of the softest position on the fruit must be carefully monitored during the delayed cooling treatment.

As peaches soften during preconditioning, they become more susceptible to impact bruising and vibration injury during distribution. Critical bruising thresholds (CBT) based on fruit flesh

Table 4. Increase $(\uparrow)$ or decrease $(\downarrow)$ in market life of preconditioned peaches at $68{ }^{\circ} \mathrm{F}\left(20.0^{\circ} \mathrm{C}\right)$ compared to untreated (no cooling delay) based on development of chilling injury (CI) during storage at 32 or $41^{\circ} \mathrm{F}\left(0.0\right.$ or $\left.5.0{ }^{\circ} \mathrm{C}\right)$.

\begin{tabular}{|c|c|c|}
\hline $\begin{array}{l}\quad \text { Change in } \\
\text { Delayed } \\
\text { cooling } \\
\text { treatment }\end{array}$ & $\begin{array}{c}\text { Change in } \\
\text { maximum } \\
\text { market life at } \\
32^{\circ} \mathrm{F} \text { (weeks) }\end{array}$ & $\begin{array}{c}\text { minimum } \\
\text { market life at } \\
41^{\circ} \mathrm{F} \text { (weeks) }\end{array}$ \\
\hline \multicolumn{3}{|c|}{ 'Flavorcrest' (1999) } \\
\hline $24 \mathrm{~h}$ at $68^{\circ} \mathrm{F}$ & 0 & $0^{1}$ \\
\hline $48 \mathrm{~h}$ at $68^{\circ} \mathrm{F}$ & 0 & $\uparrow 1+$ \\
\hline \multicolumn{3}{|c|}{ 'Elegant Lady' (1999) } \\
\hline $24 \mathrm{~h}$ at $68^{\circ} \mathrm{F}$ & 0 & 0 \\
\hline $48 \mathrm{~h}$ at $68^{\circ} \mathrm{F}$ & 0 & $\uparrow 1+$ \\
\hline \multicolumn{3}{|c|}{ 'Summer Lady' (2000) } \\
\hline $24 \mathrm{~h}$ at $68^{\circ} \mathrm{F}$ & $0^{1}$ & $\uparrow 2^{1,2}$ \\
\hline $48 \mathrm{~h}$ at $68^{\circ} \mathrm{F}$ & $\uparrow 1+$ & $\uparrow 2^{1,2}$ \\
\hline \multicolumn{3}{|l|}{ 'O’Henry' (1999) } \\
\hline $24 \mathrm{~h}$ at $68^{\circ} \mathrm{F}$ & $0^{1}$ & $0^{1}$ \\
\hline $48 \mathrm{~h}$ at $68^{\circ} \mathrm{F}$ & $\uparrow 1+$ & $\uparrow 1+$ \\
\hline \multicolumn{3}{|l|}{ 'Zee Lady' (2000) } \\
\hline $24 \mathrm{~h}$ at $68^{\circ} \mathrm{F}$ & 0 & $\uparrow 1+$ \\
\hline $48 \mathrm{~h}$ at $68^{\circ} \mathrm{F}$ & 0 & $\uparrow 1+$ \\
\hline \multicolumn{3}{|l|}{ 'Ryan Sun' (2000) } \\
\hline $24 \mathrm{~h}$ at $68^{\circ} \mathrm{F}$ & $0^{1}$ & $\uparrow 1^{1,2}$ \\
\hline $48 \mathrm{~h}$ at $68^{\circ} \mathrm{F}$ & $\uparrow 2+$ & $\uparrow 2^{2}$ \\
\hline
\end{tabular}

y End of market life based on chilling injury determined when $>25 \%$ of the fruit became mealy or leathery ${ }^{1}$, or had flesh browning ${ }^{2}$. Superscript indicates limiting condition. 
firmness and the forces of potential impacts they may encounter during postharvest handling have been developed for the most popular peach cultivars in California (Crisosto et al., 2001). These CBT values predict how much physical abuse the fruit will tolerate during packinghouse operations at different levels of flesh firmness. In general, yellow flesh peaches should be harvested and packaged at flesh firmnesses above $8 \mathrm{lbf}(35.6 \mathrm{~N})$ measured at the softest position. As peaches may soften to less than $8 \mathrm{lbf}$ during the controlled delayed cooling treatment, they must be tray packed beforehand to protect them from the physical damage they may encounter during packaging. When flesh firmness measured at the softest position is $<5 \mathrm{lbf}$, peaches become more susceptible to transportation (vibration) injury (Crisosto, unpublished data). In addition to increasing peach susceptibility to bruising, the controlled delayed cooling treatment can also increase the incidence of fruit decay and shrivel (Mitchell and Kader, 1989.). For this reason, a mixture of U.S. Environmental Protection Agency (EPA) approved fungicide and wax should be applied during packaging, before the controlled delayed cooling treatment.

Currently, there are several companies that are offering high quality preconditioned fruit based on this controlled delayed cooling treatment. This new system allows for the delivery of peaches to retail stores that are ready to buy $[\approx 6$ to $8 \mathrm{lbf}(26.7$ to $35.6 \mathrm{~N}$ ) flesh firmness measured on the cheek]. These fruit have an extended market life, based on the occurrence of internal breakdown symptoms, and a high consumer acceptance. This new fruit delivery system is one more approach to limit internal breakdown and protect the fruit eating experience for consumers.

\section{Literature cited}

Anderson, R.E. 1979. The influence of storage temperatures and warming during storage on peach and nectarine fruit quality. J. Amer. Soc. Hort. Sci. 104:459-461.

Bruhn, C.M., N. Feldman, C. Garlitz, J. Hardwood, E. Ivan, M. Marshall, A. Riley, D. Thurber, and E. Williamson. 1991. Consumer perceptions of quality: Apricots, cantaloupes, peaches, pears, strawberries, and tomatoes. J. Food Qual. 14:187-195.

Crisosto, C.H. 1997. Stone fruit ripening protocol for receivers. Slide set v98-c with cassette, Univ. Calif. Div. Agr. Nat. Resour., Oakland.

Crisosto, C.H., D. Garner, L. Cid, and K.R. Day. 1999a. Peach size affects storage, market life. Calif. Agr. 53:33-36.

Crisosto, C.H., R.S. Johnson, and T. DeJong. 1997. Orchard factors affecting postharvest stone fruit quality. HortScience 32:820-823.

Crisosto, C.H., R.S. Johnson, J.G. Luza, and G.M. Crisosto. 1994. Irrigation regimes affect fruit soluble solids concentration and rate of water loss of 'O'Henry' peaches. HortScience 29:1169-1171.

Crisosto, C.H. and J.M. Labavitch. 2002. Developing a quantitative method to evaluate peach (Prunus persica) flesh mealiness. Postharvest Biol. Technol. 25:151-158.

Crisosto, C.H., F.G. Mitchell, and Z. Ju. 1999b. Susceptibility to chilling injury of peach, nectarine, and plum cultivars grown in California. HortScience 34: 1116-1118.

Crisosto, C.H., D. Slaughter, D. Garner, and J. Boyd. 2001. Stone fruit critical bruising thresholds. J. Amer. Pomol. Soc. 55:76-81.

Garner, D., C.H. Crisosto, and E. Otieza. 2001. Controlled atmosphere storage and aminoethoxyvinyl-glycine postharvest dip delay post cold storage softening of 'Snow King' peach. HortTechnology 11: 598-602.

Haller, M.H. 1952. Handling, transportation, storage, and marketing of peaches. U.S. Dept. Agr. Bibliographical Bul. 21.

Harding, P.L. and M.H. Haller. 1934. Peach storage with special reference to breakdown. Proc. Amer. Soc. Hort. Sci. 32:160-163.

Mitchell, F.G. 1987. Influence of cooling and temperature maintenance on the quality of California grown stone fruit. Rev. Intl. Froid 10:77-81.

Mitchell, F.G. and A.A. Kader. 1989. Factors affecting deterioration rate, p. 165-178. In: J.H. Larue and R.S. Johnson (eds.). Peaches, plums and nectarines-Growing and handling for fresh market. Univ. Calif. Div. Agr. Nat. Resour. Publ. 3331.

Nanos, G.D. and F.G. Mitchell. 1991. Hightemperature conditioning to delay internal breakdown development in peaches and nectarines. HortScience 26:882-885.

Smith, W.H. 1934. Cold storage of Elberta peaches. Ice and Cold Storage 37:54-57.

Von Mollendorff, L.J. 1987. Woolliness in peaches and nectarines: A review. 1. Maturity and external factors. Horticultural Science/ Tuinbouwetenskap 5:1-3. 